\title{
Can Trade Liberalization Have Environmental Benefits in Developing Country Agriculture? A Sri Lankan Case Study
}

Jayatilleke S. Bandara, Griffith University

Ian Coxhead, University of Wisconsin-Madison

In an economy dominated by agriculture, trade policy reforms and associated changes may induce substantial reallocation of land between more and less erosive uses. However, the direction and magnitude of such a shift is difficult to predict due to the presence of existing policy distortions and of world market power in agricultural exports; moreover, changes occurring within agriculture may have economy-wide welfare effects through markets for factors and commodities. We use an applied general equilibrium model to evaluate and quantify the likely impacts of an across-the-board tariff reduction in Sri Lanka. In a related analysis, we examine the economic and environmental implications of technical progress in an important export sector, tea. We find that both types of change increase the demand for land in tea, a relatively less erosive sector, and thus have environmental as well as economic benefits for the Sri Lankan economy. (c) 1999 Society for Policy Modeling. Published by Elsevier Science Inc.

\section{TRADE LIBERALIZATION, AGRICULTURAL TECHNOLOGY, AND THE ENVIRONMENT IN SRI LANKA}

The government that came to power in Sri Lanka in 1994 pledged to continue with a program of economic liberalization

Address correspondence to Dr. I. Coxhead, University of Wisconsin-Madison, Department of Agricultural and Applied Economics, Taylor Hall, 427 Lorch Street, Madison, Wisconsin 53706.

Bandara: Senior lecturer, School of Economics, Faculty of International Business and Politics, Griffith University, Queensland, Australia. Coxhead: Associate professor, Department of Agricultural and Applied Economics, University of Wisconsin-Madison, Madison, WI, USA.

This paper is based on La Trobe University Department of Agricultural Economics Discussion Paper No. 27/95, by Bandara and Coxhead in collaboration with A. Chisholm, A. Ekanayake, and S. Jayasuriya. The authors acknowledge the support of the Australian Center for International Agricultural Research, computational advice from K. Pearson, and the research assistance of S. Somaratne. Responsibility for remaining errors is ours alone.

Received February 1996; final draft accepted July 1996.

Journal of Policy Modeling 21(3):349-374 (1999)

(C) 1999 Society for Policy Modeling

Published by Elsevier Science Inc. 
that began in the late 1970s. Then, the market-oriented United National Party (UNP) undertook significant liberalization of a previously protectionist trade policy, abolished a dual exchange rate regime, dismantled many exchange controls, and devalued the rupee. Other measures were also taken to promote exports (Rajapatirana, 1988; Cuthbertson and Athukorala, 1991; Athukorala and Jayasuriya, 1994).

The present regime also shares with most other developing country governments a growing concern with environmental quality, and increasing awareness of the environmental costs associated with traditional paths to economic development. The luxury of "get rich first, clean up later" strategies pursued a generation ago in industrializing East Asian economies is now widely acknowledged to be one that few developing economies can afford. While environmental concerns arise in almost every sector of a developing economy, land degradation is a cause for particular concern in an economy where agriculture accounts for 21 percent of GDP, is the largest employer ( $45 \%$ of the labor force), and contributes 19 percent of foreign exchange revenues, primarily through exports of tea, rubber, and coconut products (Central Bank of Sri Lanka, 1993).

In an open economy like Sri Lanka, trade policy reforms are likely to have large effects on agricultural profitability and resource allocation through direct and indirect effects on producer prices, input costs, and the nominal exchange rate. These changes, in turn, can be expected to alter household economic welfare through changes in wages, land rents, and consumer prices. In addition, if relative price changes within agriculture cause some land to be reallocated from less to more land-degrading uses, trade policy reforms could contribute to a more rapid depletion of the land resource, reducing the future productive capacity of agriculture and perhaps imposing increased costs on downstream sectors.

Traditional economic development models, and most development policies, have long adhered to free disposal assumptions with regard to agricultural growth. Land-quality degradation, erosion, and other negative side effects of output growth and land area expansion have been viewed as of secondary or negligible importance in the development process. This view is breaking down, however, in the face of mounting evidence on the economic costs of land degradation (Barbier and Bishop, 1995). Natural resource accounting studies (WRI, 1989, 1992) consistently indicate that accounting for the costs of agricultural land degradation 
leads to significant reductions in the measured rate of economic growth. The link to trade policy is evident: in an open economy with a large agricultural sector, reforms that alter the sectoral terms of trade and that within agriculture induce alterations in land use or the rate of land area expansion, may have significant effects on the generation of environmental "bads" within agriculture. Beyond this observation, however, little is known about the nature, direction, or magnitude of the influence that liberalization might exert.

In Sri Lanka, a major source of environmental damage associated with agriculture is land degradation, particularly soil erosion, on the steeply sloping lands of the central hilly regions. Land degradation directly affects the productivity of crops cultivated in the hill country. It also has off-site effects, through adverse changes in the volume and pattern of water run-off and infiltration, and through reductions in the quality of water available for hydroelectric power (HEP) generation and lowland irrigation. Gravity irrigation is the key to productivity of lowland food crop agriculture (mainly rice), and HEP is the main source of Sri Lanka's electricity supply. The choice of crops and cultivation practices in hilly regions directly affects land degradation and soil erosion rates. Therefore, policies that directly or indirectly influence upland land use patterns may have economically significant environmental effects far beyond the sectors immediately affected.

These intersectoral ramifications of upland soil erosion indicate that economic analysis of the impact of policy changes affecting land degradation, for example, through endogenous land use changes, should be conducted in a multisector framework. In this paper we use an applied general equilibrium (AGE) modeling approach. Before presenting the model and some simulation results, it is useful to provide an introduction to aspects of the tea industry, which plays a central role in land management in the hilly regions.

Sri Lanka's commercial agriculture is dominated by its tea industry. This is especially true in sloping midcountry and upland regions where soil erosion problems are most serious. Tea is the major source of foreign exchange; moreover, because Sri Lanka supplies about 18 percent of the tea traded in world markets (Ministry of Public Administration, 1994), fluctuations in Sri Lankan exports influence world tea prices. Economic reforms over the past 2 decades have addressed the need for Sri Lanka to increase export revenues, from tea as well as from other sources. 
Export taxes have been reduced (Sri Lanka Tea Board, 1994), and exchange rate adjustments reducing the degree of currency overvaluation have increased the competitiveness of Sri Lankan exports in world markets. In a similar fashion, reductions in protection for import-competing sectors can be expected to have increased tea industry profitability.

Within the tea industry, increased R\&D expenditures have led to some improvements in management practices and to rapid adoption of high-yielding vegetatively propagated (VP) tea varieties. Yields of VP tea average around $1500 \mathrm{~kg} / \mathrm{ha}$, exceeding yields from traditional cultivars growing seedling tea by about $250 \mathrm{~kg} /$ ha, or 20 percent (Fuchs, 1989). ${ }^{1}$ Because Sri Lankan exports influence world tea prices, it is equally important to examine effects of yield-increasing technical progress in tea on world and domestic prices and on the allocation of resources between tea and other sectors of the Sri Lankan economy.

Among crops growing on erosion-prone sloping lands, tea is relatively benign. Estimates of annual erosion rates under tea range from 20 tons per hectare for well-managed seedling tea on upland to medium slopes, to $75 \mathrm{t} / \mathrm{ha}$ for poorly managed seedling tea on high slopes (Bandarathilake, 1994). By contrast, other annual crops commonly grown on sloping uplands-tobacco, vegetables, and various forms of shifting cultivation-contribute to erosion at rates in the region of 70-100 t/ha per year.

In 1989, tea occupied 56 percent of nonforest agricultural land in the highlands, and 23 percent in midlands (Bandara and Coxhead, 1995). However, the overall area planted to tea fluctuates by a surprising amount from year to year. Table 1 shows that in the decade from 1983, tea area declined by 5 and 12 percent in highlands and midlands, respectively. During the same period, the average absolute year-on-year percentage change in tea area was about 1,2 , and 3 percent, respectively, for highlands, midlands, and lowlands. We infer from these data that in spite of a relatively stable overall tea area, at the margin there is considerable land substitution between tea and other crops. Among other causes, these fluctuations presumably reflect changes in relative profitability between tea and other crops. Any answer to the question of the effects of trade policy reforms or technical progress on

\footnotetext{
${ }^{1}$ Plans to privatize the largely State-owned estate tea sector may also alter productivity, investment, and profitability in the future.
} 
Table 1: Tea Area and Annual Changes (Absolute Values), by Elevation 1983-92

\begin{tabular}{|c|c|c|c|c|c|c|c|c|}
\hline \multirow[b]{2}{*}{ Year } & \multicolumn{2}{|c|}{ High } & \multicolumn{2}{|c|}{ Medium } & \multicolumn{2}{|c|}{ Low } & \multicolumn{2}{|c|}{ All } \\
\hline & $\begin{array}{c}\text { Area } \\
\text { (ha) }\end{array}$ & $\begin{array}{c}\text { Change } \\
(\%)\end{array}$ & $\begin{array}{c}\text { Area } \\
\text { (ha) }\end{array}$ & $\begin{array}{c}\text { Change } \\
(\%)\end{array}$ & $\begin{array}{c}\text { Area } \\
\text { (ha) }\end{array}$ & $\begin{array}{c}\text { Change } \\
(\%)\end{array}$ & $\begin{array}{c}\text { Area } \\
\text { (ha) }\end{array}$ & $\begin{array}{c}\text { Change } \\
(\%)\end{array}$ \\
\hline 1983 & 77769 & & 96644 & & 67728 & & 242141 & \\
\hline 1984 & 74157 & -4.64 & 90203 & -6.66 & 63514 & -6.22 & 227885 & -5.89 \\
\hline 1985 & 74705 & 0.74 & 89176 & -1.14 & 67769 & 6.70 & 231652 & 1.65 \\
\hline 1986 & 73206 & -2.01 & 85216 & -4.44 & 64483 & -4.85 & 222911 & -3.77 \\
\hline 1987 & 72773 & -0.59 & 84445 & -0.90 & 64280 & -0.31 & 221499 & -0.63 \\
\hline 1988 & 72901 & 0.18 & 84227 & -0.26 & 64555 & 0.43 & 221683 & 0.08 \\
\hline 1989 & 73110 & 0.29 & 84062 & -0.20 & 64938 & 0.59 & 222110 & 0.19 \\
\hline 1990 & 73138 & 0.04 & 83223 & -1.00 & 66397 & 2.25 & 222759 & 0.29 \\
\hline 1991 & 73331 & 0.26 & 82467 & -0.91 & 66893 & 0.75 & 222692 & -0.03 \\
\hline 1992 & 74141 & 1.10 & 85510 & 3.69 & 62185 & -7.04 & 221841 & -0.38 \\
\hline \multicolumn{9}{|c|}{$\begin{array}{l}\text { Ave. annual } \\
\text { change (abso- } \\
\text { lute value) }\end{array}$} \\
\hline SD & & 1.46 & & 2.26 & & 2.93 & & 2.05 \\
\hline
\end{tabular}

Source: Calculated from data in Ministry of Public Administration (1994).

agricultural land degradation must, therefore, take account of induced increases or reductions in tea area, and corresponding reductions or increases in the area planted to other, typically more erosive crops. Moreover, given the importance of agriculture for income, employment, and export revenues, any corresponding change in land degradation is likely to have significant consequences for economic welfare, augmenting or perhaps offsetting the effects of reforms such as trade policy liberalization.

Our measure of land degradation will rely entirely on land allocation among agricultural sectors-specifically between tea and crops that are primarily import competing, in middle and high altitude areas. Our primary objective is, thus, to predict changes in agricultural land allocation caused by exogenous "shocks" such as trade liberalization or technical progress. Given this, an AGE approach may at first seem superfluous. After all, trade theory provides fairly detailed predictions of the resource allocation effects of sectoral changes in relative prices and factor productivity. In a small open economy with no initial distortions other than a tariff, trade liberalization will cause resources to flow into sectors producing exportables and out of those producing importables, 
and will have ambiguous effects on sectors producing non-tradables. Therefore, we might predict trade liberalization to bring about an expansion of (exportable) tea production and a corresponding decline in land degradation as land and other resources are attracted out of import-competing sectors associated with higher land degradation rates. Similarly, technical progress in tea should cause that sector to expand at least as rapidly as the rate of technical progress itself, for given prices, and so again have a beneficial environmental impact by drawing land out from production of more erosive crops and into tea.

However, the Sri Lankan economy is characterized by numerous policy distortions that render these stylized predictions uncertain, and even raise the possibility that trade liberalization or technical progress in tea could reduce aggregate welfare. Moreover, the country faces downward-sloping demand for its tea exports, and this violation of the small country assumption again raises the prospect of immizerizing as well as environmentally damaging growth. In these circumstances a numerical solution is merited; an AGE model is more likely to capture complex intersectoral relationships transmitted through policy-distorted commodity and factor markets.

\section{AN AGE MODEL OF THE SRI LANKAN ECONOMY}

Sri Lanka was one of the first LDCs in which AGE models were used for economic analysis (Bandara, 1990). However, their acceptance as tools for policy analysis has been comparatively slow in that country. In recent years, two similar AGE models were developed for Sri Lanka (Bandara, 1989; CIE, 1992). Both are neoclassical comparative-static models similar in structure to the ORANI model of the Australian economy (Dixon et al., 1982). The CIE model is the more disaggregated of the two and uses a more recent input-output database. We therefore, adopt this model as our starting point, adapting and extending it to serve the aims of our study.

The CIE model belongs to a class of AGE models that are linear in proportional changes of variables. Such models can be used to address a range of comparative static questions about changes in policies, prices, endowments, and technology in the real economy. Models of this type cannot simulate the time path of an economy; however, they are well suited to providing insights into the implications of shocks that carry the economy away from previously established trends. 
The CIE model has 35 industries, each producing a single good and using intermediate goods and three primary factors-capital, land, and a composite labor with skilled, unskilled, and rural components (see the Appendix for a summary of the model's structure and solution method). For the purpose of our study we extend and expand this model. Specifically, we extend the model to 37 industries by dividing two sectors-tea and "other agriculture" (a composite consisting mainly of import-competing cash crops)—into "upland" and "lowland" subsectors. This division admits differential rates of productivity growth of the same crop in different environments, and also allows some agricultural land to be mobile between subsectors (in this case, between tea and "other agriculture") in each land category, upland and lowland. ${ }^{2}$ By this means, changes in the relative profitability of tea and "other agriculture" will be reflected in a reallocation of land between the subsectors, with implications for aggregate erosion rates when the two industries have different degrees of erosivity. Land in the remaining agricultural sectors is regarded as specific to those sectors, just as physical capital is regarded as specific to most nonagricultural sectors.

The model database uses input-output data to compute initial sector shares in input demand, sales, and trade; factor shares in income, and related parameters. An elasticity data set contains parameters governing substitution among primary factors (including different categories of labor), as well as export demands, household expenditures, and price responses. We obtain the I-O data from 1989 Sri Lanka I-O tables. ${ }^{3}$ In the absence of suitable estimates from Sri Lankan data we use elasticity values based on existing literature and knowledge of Sri Lankan conditions. Armington elasticities of substitution between domestic and imported goods are assigned default values of 2.0. Elasticities of factor substitution are set on the basis of assumed supply elasticities of 0.5 for plantation agriculture, 0.75 for other agriculture, and 1.0 for all remaining industries. Elasticities of substitution between labor of different types are set at 0.1. Export demand elasticities are set at 20 in all sectors except tea processing, where this parameter takes a value of 10 to reflect Sri Lanka's influence in world

\footnotetext{
${ }^{2}$ Factors are termed "mobile" if they can be used in more than one sector. Those that can be used only in a particular sector are said to be "specific" to that sector.

${ }^{3}$ The 1989 data, the most recent compiled by the National Planning Division of the Ministry of Finance and Planning, are in turn revised and updated from a 1986 I-O database.
} 
tea markets. The values of some parameters are likely to be of considerable importance to the model's results. Later in this paper we summarize the results of sensitivity analyses with respect to some key values.

Domestic commodity and factor prices are determined by market-clearing conditions as follows. Domestic prices of tradables are equal to border prices adjusted by trade taxes. Border prices of importables are exogenous (the small country assumption); for exports, border prices depend on the elasticity of export demand as just described. Land is fixed in each agricultural sector, except (as noted above) that upland land and lowland land endowments are mobile between tea and "other agriculture" in their respective regions. Capital is fixed in each nonagricultural industry except the tea-processing sector. This sector, the sole purchaser of leaf tea and exporter of tea products, is known to have substantial excess capacity: by assuming its capital endowment to be endogenous at a fixed rate of return set in the rest of the economy, we ensure that this sector's output adjusts to accommodate any increases or reductions in leaf tea production. In labor markets, we assume that real wages are fixed and allow aggregate employment to be determined within the model.

The macroeconomic closure can be treated in several alternative ways. For this study we set real consumption endogenous and impose a trade balance constraint. The model thus indicates the change in real absorption that would be required by a given trade deficit or surplus. We adopt the foreign currency exchange rate as a numeraire price; any change in domestic prices can thus be interpreted as a change relative to world prices, and movements in the domestic price level represent shifts in the real exchange rate, defined as the ratio of an index of the border prices of tradeables to an index of domestic prices. Finally, all taxes, subsidies and government demands are also assumed to be exogenous.

\section{A. Modeling Erosion and Land Degradation}

In tropical countries, upland soil erosion rates are higher, for given slope and soil type, when soil is frequently tilled or otherwise exposed to rain and wind. Erosion rates are thus higher-often much higher-when land is used to produce annual or shortseason crops requiring frequent tillage than when it is planted to perennial crops (Repetto, 1989). Table 2 shows that most erosion 
Table 2: Sectoral Erosion Contributions and Annual Aggregate Value of Soil Erosion in Sri Lanka (US\$)

\begin{tabular}{lcccrrr}
\hline \multicolumn{1}{c}{ Crop } & $\begin{array}{c}\text { Erosion } \\
\text { rate (ave) } \\
\text { (tons/ha/yr) } \\
(\mathbf{1})\end{array}$ & $\begin{array}{c}\text { Highland } \\
\text { (ha) }\end{array}$ & $\begin{array}{c}\text { Midland } \\
\text { (ha) }\end{array}$ & $\begin{array}{c}\text { Total } \\
\text { (ha) } \mathbf{( 2 )}\end{array}$ & $\begin{array}{c}\text { Value of } \\
\text { soil loss } \\
(\mathbf{( 3 )})^{a}\end{array}$ & \multicolumn{1}{c}{$\begin{array}{c}\text { Share } \\
(\mathbf{\%})\end{array}$} \\
\hline Tea & 17.5 & 73,110 & 84,062 & 157,172 & $4,257,311$ & 27.7 \\
Rubber & 10.0 & & 97,416 & 97,416 & $1,507,830$ & 9.8 \\
Coconut & 10.0 & & 55,529 & 55,529 & 859,492 & 5.6 \\
Export ag. & 10.0 & 3,692 & 35,956 & 39,648 & 613,682 & 4.0 \\
Other ag. & 85.0 & 26,788 & 28,500 & 55,288 & $7,273,978$ & 47.2 \\
Forestry & 2.0 & 120,444 & 160,669 & 281,113 & 870,228 & 5.7 \\
Grand total & $14.5^{b}$ & 224,034 & 462,132 & 686,166 & $15,382,521$ & 100.0 \\
\hline
\end{tabular}

Sources: (1) Bandarathilake (1994); (2) Ministry of Public Administration (1994); and (3) Department of Census and Statistics, Sri Lanka (1994).

${ }^{a}(3)=(1) *(2) * 1.55$, where nutrient loss is valued at $\$$ U.S. 1.55/ton/year (Clark 1994).

${ }^{b}$ Weighted average.

(on a per hectare basis) in Sri Lanka is due to cultivation of shortseason commercial crops rather than perennials such as tea and rubber. Therefore, conversion of land from perennial to annual crops is associated, ceteris paribus, with increased erosion.

Upland erosion reduces on-site land productivity, because topsoil loss removes nutrients and leads to degradation of soil structure. Downstream, adverse off-site effects of erosion appear as diminished water quality, accelerated sedimentation of dams and canals, and in some areas alterations in the quantity and seasonal pattern of both flooding and controlled water delivery. There may be long lags between the occurrence of erosion in uplands and its downstream impacts: with the exception of "spike" events, such as storms and flash floods, the full off-site effects of topsoil loss from uplands may be felt over decades rather than years.

To model all the effects of erosion is an extremely complex task, and requires detailed physical and biological data that are rarely, if ever, available. Some guesswork as to key parameter values is inevitable. Given this constraint, we make a number of assumptions to arrive at a description of the production and consumption of erosion that makes full use of available data without introducing large numbers of parameters for which no data exist. For a given exogenous shock (e.g., a trade policy change) we attempt to measure and to value changes in the amount of 
erosion produced in upland agriculture. We assign a value to onsite losses by calculating the replacement cost of nutrients removed from the soil (see below). For lowland agriculture and electricity generation sectors we assume that erosion-related water pollution increases costs in a way analogous to factor-biased technical regress-by reducing the productivity of fixed capital.

\section{B. On-Site Effects ${ }^{4}$}

We begin by defining total erosion ( $E$, measured as total tons of soil lost per year), as the sum over $N$ sectors of per hectare erosion rates, $R_{i}$, multiplied by land area, $Z_{i}$ :

$$
E=\Sigma_{i} Z_{i} R_{i} \quad(i=1, \ldots, N) .
$$

Converting this expression to proportional changes of variables (defined by lower case characters, so $x=d X / X$ for each variable $X$ ), we obtain an expression for the change in total upland erosion as the weighted sum of sectoral area and erosion rate changes, the weights being each sector's base year contribution to total erosion:

$$
e=\Sigma_{i} \alpha_{i}\left(z_{i}+r_{i}\right) \quad(i=1, \ldots, N),
$$

where $\alpha_{i}=Z_{i} \mathrm{R}_{i} / E$. Each crop grown in each region (upland or lowland) is associated with a specific erosion rate. We assume that in proportional change terms, erosion in sector $i$ is linearly related to land use in that sector - that is, we abstract from the possibility that land quality differences, management practices, or investments in soil-conserving technology might alter the erosion rate associated with each crop and each ecosystem by setting $r_{i}=0$. Thus:

$$
e=\Sigma_{i} \alpha_{i} z_{i}
$$

Land use changes $\left(z_{i}\right)$ are endogenously related to changes in prices, production, and technology through CES agricultural input demand functions derived from the cost-minimizing behavior of firms. To expand the model structure described in the Appendix, let $Y_{j}$ denote the output of sector $j ; W_{k j}$ be the price of input $k$ used in sector $j$, and let $T_{j}$ and $T_{k j}$, respectively, be sector-wide and input-specific rates of technical progress. We then write the demand for land in sector $j, Z_{j}$ with price $W_{z j}$, in proportional

\footnotetext{
${ }^{4}$ This section draws on analyses in Coxhead and Shively (1995).
} 
change form as:

$$
z_{j}=y_{j}-\sigma_{j}\left[w_{z j}-\Sigma_{k} w_{k j} \theta_{k j}\right]-\sigma_{j}\left[t_{z j}-\Sigma_{k} t_{k j} \theta_{k j}\right]-t_{j},
$$

where $\sigma_{j}$ is the elasticity of substitution among inputs in sector $j$ and $\theta_{i j}=W_{i} X_{i j} / \Sigma_{k} W_{k} X_{k j}$ is the value of payments to factor $i$ as a fraction of total costs in sector $j$. By Equation 4, if relative factor prices and technology remain unchanged, land use in the sector will increase or decline in direct proportion to output. If factor prices or technology also change, land use in the sector will be modified accordingly; thus, by Equation 3, the production of aggregate erosion will also change. In our model, values of $Y_{j}, W_{i j}$, and $Z_{j}$ are endogenous and the $T_{i j}$ s are exogenous.

Total land area of each type is constrained by assuming no change in aggregate land supply, thus maintaining our mediumrun focus on resource reallocation among sectors. Land in each region is mobile between tea and "other agriculture" subsectors; its price is determined by a market clearing condition:

$$
\Sigma \zeta_{i}^{r} z_{i}^{r}=0
$$

for all $r=$ \{upland, lowland $\}$, where $i=\{$ tea, "other agriculture" $\}$ and $\zeta_{i}^{r}=Z_{i}^{r} / \Sigma_{i} Z_{i}^{r}$ are initial shares of each subsector in total use of land of type $r$. Because land is mobile among these subsectors, a change that increases profitability in either the tea or "other agriculture" subsector will induce reallocation of land between the two, and thus alter the rate at which erosion is generated. This mechanism is the core of the environmental component of our model.

If there is no change in land use in a sector, then that sector's production of erosion will remain at the base level, for given management practices. A land-use change may occur either through changes in the derived demand for land as sectoral output levels rise or fall, or through changes in relative factor prices and, hence, substitution of land for other factors, or through factorbiased technical progress. In Section 3 we examine technical progress and the relative price effects of trade liberalization as sources of agricultural land reallocation. However, the land market specification of Equations 4-5 allows for a much more diverse set of influences.

To implement the on-site land degradation accounting described by Equations $1-5$, the only new data we require are estimates of the sectoral erosion share weights $\alpha$. These are calculated from data shown in Table 2. All other data are drawn from the existing model database. 


\section{C. Off-Site Effects}

The main off-site impact of erosion is to reduce the productivity of physical structures for the storage and delivery of water for irrigation and HEP generation. An increase in the sediment delivery rate to these structures thus raises costs directly in irrigated agriculture and HEP sectors. Degradation of physical capital is the equivalent of non-neutral technical regress in the affected sectors because sector-specific capital is directly affected, while mobile factor productivity may be altered by a smaller amount or not at all (Coxhead, 1994). At constant prices, output of each affected sector will decline by an amount governed by the initial contribution of the specific factor to total value added in the sector, and by the degree of input substitutability. Consider the supply function $Y_{j}$ of the $j$ th lowland sector employing mobile labor $\left(L_{j}\right)$ and sector-specific capital $\left(K_{j}\right)$, derived from the maximization of aggregate income subject to factor endowment constraints: ${ }^{5}$

$$
Y_{j}=Y_{j}\left(\mathbf{P}, L_{j}\left(\mathbf{P}, W ; K_{j}\right) ; K_{j}\right),
$$

where the effective sector-specific capital stock is a declining function of aggregate erosion: $K_{j}=K_{j}(E), \partial K_{j} / \partial E<0$. Converting Equation 6 to proportional changes of variables, we observe the effects of changes in prices and erosion on output as:

$$
y_{j}=\left(\epsilon_{j j}+\epsilon_{j i} \epsilon_{l j}\right) p_{j}+\epsilon_{j l} \epsilon_{l j} w+\epsilon_{k e}\left(\epsilon_{j i} \epsilon_{l k}+\epsilon_{y k}\right) e,
$$

where:

$$
\begin{gathered}
\epsilon_{j j}=\frac{\partial Y_{j} / \partial P_{j}}{Y_{j} / P_{j}}>0 \\
\epsilon_{j l}=\frac{\partial Y_{j} / \partial L_{j}}{Y_{j} / L_{j}}>0 \\
\epsilon_{l j}=\frac{\partial L_{j} / \partial Y_{j}}{L_{j} / Y_{j}}>0 \\
\epsilon_{l w}=\frac{\partial L_{j} / \partial W}{L_{j} / W}<0
\end{gathered}
$$

\footnotetext{
${ }^{5}$ We obtain Equation 6 from the first-order conditions of aggregate revenue maximization with respect to commodity price. In a competitive economy with no externalities the optimal allocation of a mobile factor to price-taking sector $j$ will be the same as the profitmaximizing amount of the factor demanded by that sector. Thus $L_{j}\left(\mathbf{P}, W, K_{j}\right)$ in Equation 6 is the labor-demand function obtained by maximization of the restricted profit function $\pi^{j}\left(\mathbf{P}, W, K_{j}\right)$ with respect to $W$ (Cornes, 1992; p. 122).
} 


$$
\begin{gathered}
\epsilon_{l k}=\frac{\partial L_{j} / \partial K_{j}}{L_{j} / K_{j}} \gtrless 0 \\
\epsilon_{y k}=\frac{\partial Y_{j} / \partial K_{j}}{Y_{j} / K_{j}}>0 \\
\epsilon_{k e}=\frac{\partial K_{j} / \partial E}{K_{j} / E}<0 .
\end{gathered}
$$

Note that $\epsilon_{k e}$ is the elasticity of the impact of erosion on specific capital productivity.

At constant prices and for given capital endowments, a change in erosion reduces lowland sectors' output by diminishing their effective specific factor endowment. The extent of the output decline is governed by the initial contribution of the specific factor to sectoral value added and by the degree of substitutability of other inputs for the factor. If $L_{j}$ and $K_{j}$ are complements $\left(\epsilon_{l k}<\right.$ $0)$, then the output decline is unambiguous. If they are substitutes, the direct effect of erosion on the effective capital stock in a sector may be reduced by substitution of labor for capital.

The only parameter values in Equations 1-7 that cannot be calculated from the existing model database or homogeneity conditions are the $\epsilon_{k e}$ elasticities, describing the direct productivity impact of erosion in lowland sectors. There is little empirical guidance for these values. An econometric study of Philippine irrigation systems estimated that every one-percent increase in upland rice and corn area reduced downstream irrigated area by 0.15 percent (Masicat, de Vera, and Pingali, 1990). Guided by this, we adopt a value of $\epsilon_{k e}=-0.1$ in the paddy and HEP sectors, and $\epsilon_{k e}=0$ in all other sectors.

\section{D. Aggregate Welfare and the Distribution of Income}

Erosion and land degradation studies usually calculate damage costs in terms only of lost agricultural income, with a few studies also including physical off-site effects. However, in the absence of a Coasian solution or Pigovian tax, an activity producing negative externalities may generate social costs not only in sectors physically affected by the damage, but also, by inducing reallocation of resources, in sectors physically affected. For example, if productivity in electricity generation is reduced by dam siltation and accelerated turbine wear, all sectors face increased power costseither directly, through higher input prices, or indirectly, through 
the current account impact of additional fuel imports required to meet domestic demand. Relative to the socially optimal resource allocation, an externality is like a subsidy to the polluting sector (or equivalently, a tax on affected sectors). In general equilibrium, we seek to measure and to value erosion damages both at the level of individual sectors and the aggregate economy, capturing indirect efficiency and resource misallocation losses in a broader welfare measure.

When externalities reduce factor productivity in some industries, their welfare impact is captured by conventional national accounts measures in the form of reduced output (calculated at constant prices) or altered factor incomes. However, the on-site costs of soil erosion are not captured because the national accounts have no place in which such depletion of a resource endowment is recorded. For a given exogenous shock, therefore, we calculate changes in national income as conventionally measured, then compare them with the value of on-site soil degradation gains or losses from induced changes in agricultural land use. Thus, for example, the impact of a policy change on conventional measures of national income may in "net" terms be augmented or diminished by a corresponding reduction or increase in land degradation. ${ }^{6}$

\section{SIMULATION EXPERIMENTS}

What are the economic effects of a general reduction in import protection or an increase in the rate of technical progress in tea sectors? In this section we report the results of simulation experiments addressing these questions. We assess likely consequences of each shock for the production of soil erosion, and assign values to on-site land degradation losses by calculating the value of lost soil nutrients and organic matter. As previously noted, we employ a closure in which real wages and the balance of trade are fixed. Labor markets thus clear through quantity adjustments, and aggregate net income changes appear as changes in real household consumption. For brevity, our presentation and discussion of the results focuses on resource reallocation in agriculture and changes in aggregate economic welfare.

\footnotetext{
${ }^{6}$ Our approach is consistent with the treatment of investment in a static model, in which it is customary to calculate the value to the net change in investment, but not to record investment-related output changes.

${ }^{7}$ Full details of each experiment and results are available as a set of data and program files from the authors.
} 


\section{A. Trade Liberalization}

Trade liberalization promotes the production of exportables and reduces incentives to produce importables, other things equal. In our case, tea is exportable (all leaf tea is sold to the exportoriented tea processing sector), while commercial crops produced in the "other agriculture" sector are mainly import competing. Liberalization should, therefore, cause expansion of tea area at the expense of importable crops, and thus reduce erosion. The combined effect of reduced erosion and reduced distortions should increase welfare. However, these predictions are rendered ambiguous by several complications. First, Sri Lankan tea exports influence world prices, which raises the possibility of immizerizing growth. Second, the degree to which imports can be substituted for domestically produced commercial crops also matters. If Armington elasticities are low, trade liberalization may have little or not effect on the prices of commercial crops grown domestically. Third, in a significantly distorted economy, trade liberalization without corresponding changes in other policies may reduce welfare rather than raising it. Therefore, the sign and magnitude of the impact of trade liberalization on upland allocation and on aggregate welfare is uncertain.

We approximate trade liberalization by exogenously reducing all import tariff rates by 25 percent. ${ }^{8}$ The results of this simulation are given in the first columns of Tables 3 and 4 (complete sectoral output results are shown in Appendix Table A1). They show that in spite of the complicating factors raised in the previous paragraph, reducing tariffs has predictable results on the overall structure of production, in general causing the output of exportables to increase and that of import-competing goods to decline. The reform raises both real GDP and real consumption. These welfare gains are positive in spite of the fact that increased tea exports drive down the world tea price by 0.5 percent (Table 4 ).

Trade reform also influences land use. Tea production increases, and that of the upland "other agriculture" sector declines, in spite of the decline in tea prices. As a result of the relative price movement, upland is reallocated to tea production, and-because the erosion rate in upland tea is lower than that in upland "other

\footnotetext{
${ }^{8}$ The base tariff rates are reported in Bandara and Coxhead (1995). Implicit rates were computed by dividing duty collections on each good by the value of imports of that good. Calculated in this way, the simple average tariff rate is 22 percent.
} 
Table 3: Selected Effects of Tariff Reduction and Technical Change Shocks on Production, Factor Demand, and Erosion (Percent Changes)

\begin{tabular}{lcc}
\hline Endogenous variable & $\begin{array}{c}\text { 25\% Tariff } \\
\text { reduction }\end{array}$ & $\begin{array}{c}\text { 10\% Technical } \\
\text { progress in tea }\end{array}$ \\
\hline Output & & \\
$\quad$ Upland tea & 2.8 & 13.0 \\
$\quad$ Lowland tea & 6.5 & 16.7 \\
Rubber & 1.1 & -2.3 \\
Coconut & 0.6 & 0.6 \\
Paddy & 0.3 & 0.5 \\
$\quad$ Export agr. & 0.7 & -1.6 \\
$\quad$ Upland other agr. & -1.1 & -1.1 \\
$\quad$ Lowland other agr. & -0.4 & -0.3 \\
Exports & & 16.6 \\
$\quad$ Processed tea & 5.0 & 3.7 \\
Labor demand & & 7.5 \\
$\quad$ Upland tea & 3.6 & 1.5 \\
$\quad$ Lowland tea & 7.3 & 6.5 \\
Land use & & -0.7 \\
$\quad$ Upland tea & 1.4 & \\
$\quad$ Lowland tea & 6.3 & 0.07 \\
Aggregate erosion & -0.7 & 0.07 \\
Sp. Fac. productivity & & \\
$\quad$ Paddy & 0.07 & \\
HEP generation & 0.07 & \\
\hline
\end{tabular}

${ }^{a}$ Sectors directly affected by off-site effects of erosion.

agriculture"-aggregate soil erosion declines. A lower upland erosion rate increases productivity growth in downstream sectors (paddy rice and HEP) by 0.07 percent. These gains contribute directly to the measured aggregate welfare increase.

\section{B. Technical Progress in Tea}

In our second simulation we examine the effect of technical progress in tea production, in the form of a 10-percent productivity increase. This simulation thus explores the likely impacts of more wide-spread adoption of VP tea technology which, as noted above, is associated with yield increases of about 25 percent over traditional cultivars. At constant product prices we expect technical progress of this form to promote expansion of tea area at the expense of other land uses. However, the increase could be diminished in size or even reversed either by a large endogeneous 
Table 4: Effects of Tariff Reduction and Technical Change Shocks on Selected Prices and Macro Variables (Percent Changes)

\begin{tabular}{lcc}
\hline Endogenous Variable & $\begin{array}{c}\mathbf{2 5 \%} \text { Tariff } \\
\text { reduction }\end{array}$ & $\begin{array}{c}\text { 10\% Tech. } \\
\text { progress in tea }\end{array}$ \\
\hline Border price of tea & -0.5 & -1.7 \\
Domestic producer price of tea & 1.0 & -4.8 \\
Nominal GDP & -1.3 & 3.7 \\
Nom. h'hold disp. income. & -1.3 & 3.7 \\
GDP deflator & -1.7 & 2.8 \\
Cons. price index & -1.2 & 2.9 \\
Imports (foreign currency) & 1.4 & 1.5 \\
Exports (foreign currency) & 1.6 & 1.7 \\
Real GDP & 0.5 & 0.8 \\
Change in gov't budget $\left(\mathrm{Rp} * 10^{6}\right)$ & 2887 & 1455 \\
Real h'hold consumption & 0.6 & 1.0 \\
Aggregate employment & 1.1 & 0.9 \\
\hline
\end{tabular}

decline in the world tea price, or by the effects of other distortions already present in the economy.

As Tables 3 and 4 reveal, technical progress in tea results in increased tea output, and thus draws resources out of the "other agriculture" sector-as occurred in the trade liberalization case. By coincidence, the macro results for a 10 percent rate of technical progress are very similar to those of trade liberalization. Aggregate agricultural erosion again declines, by about 0.7 percent. The smaller decline in overall erosion contributes to a somewhat smaller, but nonetheless significant, productivity increase in downstream sectors. Together, the direct productivity gain from technical progress and its off-site and intersectoral effects contribute to approximately 1 percent increases in real GDP and real household consumption (Table 4, col. 2). Because on-site land degradation is also reduced, the net welfare impact of the technical progress is unambiguously positive.

\section{C. Valuing Erosion Changes}

What is the economic significance of the declines in aggregate erosion observed in both the trade policy reform and technical progress experiments? A complete valuation is a very complex undertaking, taking us well beyond the scope of this study. However, we can at least suggest some figures on the basis of the following simple calculations. 
A recent soil loss study has estimated that on average, each ton of upland soil lost through erosion in Sri Lankan agriculture has a value, in terms of nutrients removed, of \$U.S. 1.55 (Clark, 1994). ${ }^{9}$ If upland and midcountry agricultural land erodes at an average rate of 14.5 tons per hectare per year (Table 2), then the annual aggregate on-site value of agricultural erosion in terms of lost nutrients is: $\$$ U.S.1.55 * 14.5 tons/ha $* 686,166$ ha of high and midcountry agricultural land = \$U.S.15.4 million/yr, (or Rs.675 million) or 0.17 percent of 1992 GDP.

Our first experiment indicates that tariff reduction reduces aggregate soil erosion by 0.7 percent. By the method just presented, trade liberalization thus contributes to an annual reduction of \$U.S.15.4 million*0.007 = U.S.\$108,000 (or Rs.4.7 million) in onsite land degradation, in addition to the measured real income gain shown in Table 4. In addition to its conventionally measured economic benefits, a 10-percent rate of neutral technical progress in tea, by causing some land to be removed from production of more erosive crops, reduces on-site land degradation by the same value. $^{10}$

In terms of GDP, these numbers may appear small at first glance-even recognizing that they represent only the value of on-site changes. However, they represent a much more substantial fraction of annual expenditures by the Sri Lankan government directed both at erosion control and at cleaning up some of the indirect damages caused by erosion. Our experiments indicate that substantial reductions in erosion-and, therefore, large savings in defensive expenditures, maintenance of dams and irrigation systems, replacement of electricity generating turbines, etc.-may be achievable through indirect means. In the case of trade liberalization, the outcome strongly suggests that "win-win" combinations of liberalization and reduced land degradation may be achievable in some developing countries.

\footnotetext{
${ }^{9}$ The soil nutrient loss method has several weaknesses in estimating the true cost of land degradation. Thus, as it ignores the possibility that the impact of the lost nutrients may not be felt on crop productivity until some-possibly distant-time in future, it tends to overestimate the actual cost. On the other hand, changes in land quality, such as soil compaction, which may have significant and immediate adverse effects on productivity are not incorporated into the loss estimate.

${ }^{10}$ For more detail on nutrient loss and replacement calculations, see Bandara and Coxhead (1995).
} 


\section{D. Sensitivity Analysis}

In simulation models the lack of statistical confidence intervals demands some investigation of the robustness of results with respect to assumed parameter values. Experience shows that simulation results in open economy models are especially sensitive to the values of Armington elasticities and export demand elasticities, because these parameter values, by limiting the extent of substitution between domestic and foreign goods, play a big role in determining domestic prices. Other parameter values more directly related to sectors affected by an exogenous change also merit investigation. As a first step we examined the robustness of our results with respect to the values of Armington elasticities. A 10percent increase in all Armington elasticity values produced only very minor changes in the results of Tables 3 and 4 (complete results are available from the authors).

Our data embody the assumption that Sri Lanka is a price taker in all export markets except that for tea, for which we assumed an export demand elasticity of -10 . Our second sensitivity analysis explores the effect of doubling this value (to -20 , bringing it into line with export demand elasticities for other goods). Our results are somewhat sensitive to this change, which has the effect of damping domestic tea price declines attributable to world price effects when Sri Lankan tea exports increase. Predictably, the diminished price decline means that in both the trade liberalization and technical change experiments, tea sectors expand by more than in the base case. Accordingly, in the sensitivity analysis aggregate erosion is reduced by more than in the base case. The "sensitivity elasticity" (Pagan and Shannon, 1985) of the erosion result with respect to the tea export demand elasticity is about 0.1 : that is, for every 1 percent increase in the value of the tea export demand elasticity, our estimates of the reduction in erosion increase by about 0.1 percent over the base case.

Our third sensitivity analysis focuses on the valuation of changes in erosion. Our calculations of this value depend on assumptions about the average per hectare annual rate of soil loss (14.5 tons) and the average values of nutrients lost per ton $(\$ 1.55$ in the base case). Table 5 shows the variation in our results obtained by altering each of these values by plus or minus 50 percent. In the base case, we estimate the value of annual on-site erosion costs at 0.17 percent of GDP. In the sensitivity analysis this value ranges from 0.04 to 0.38 . By the same calculation, our estimate of the 
Table 5: Sensitivity Analysis: Value of Erosion Losses with Respect to Estimates of Erosion Rate and Unit Nutrient Replacement Cost

\begin{tabular}{|c|c|c|c|c|c|}
\hline & & & \multicolumn{3}{|c|}{ Nutrient replacement cost (\$US/t) } \\
\hline \multirow{2}{*}{\multicolumn{3}{|c|}{ 1. Base data }} & 0.775 & 1.55 & 2.325 \\
\hline & & & low & base & high \\
\hline \multirow[t]{3}{*}{ Erosion rate $(\mathrm{t} / \mathrm{ha} / \mathrm{yr})$} & 7.25 & low & $3,855,395$ & $7,710,790$ & $11,566,186$ \\
\hline & 14.5 & base & $7,710,790$ & $15,421,581$ & $23,132,371$ \\
\hline & 21.75 & high & $11,566,186$ & $23,132,371$ & $34,698,557$ \\
\hline \multicolumn{6}{|c|}{ 2. Initial erosion losses as percent of $\mathrm{GDP}^{a}$} \\
\hline & & & low & mid & high \\
\hline \multirow[t]{3}{*}{ Erosion rate } & & low & 0.04 & 0.08 & 0.13 \\
\hline & & base & 0.08 & 0.17 & 0.25 \\
\hline & & high & 0.13 & 0.25 & 0.38 \\
\hline \multicolumn{6}{|c|}{ 3. Value $\$$ US of $0.7 \%$ reduction in erosion ${ }^{b}$} \\
\hline \multirow{4}{*}{ Erosion rate } & & & low & mid & high \\
\hline & & low & 26,988 & 53,976 & 80,963 \\
\hline & & base & 53,976 & 107,951 & 161,927 \\
\hline & & high & 80,963 & 161,927 & 242,890 \\
\hline
\end{tabular}

${ }^{a} \mathrm{GDP}=\$ \mathrm{US} 9,071,518,235$ in 1992.

${ }^{b}$ As a share of 1992 GDP these figures range from 0.03 to 0.27 percent.

annual gains from reduced erosion due to trade liberalization ranges from a low of $\$$ U.S.65,000 to a high to $\$$ U.S.590,000. In the technical progress experiment the same gains range from $\$$ U.S.23,000 to $\$ 200,000$. These ranges indicate the importance for policy purposes of seeking more information about direct physical and economic impacts of erosion in Sri Lanka.

The importance of sensitivity analysis becomes apparent when we compare the price effects of the two exogenous shocks reported in this paper. In the first experiment, trade liberalization raises the price of tea to producers and leads to an expansion in tea area; this price increase is not fully negated by the depressing effect of higher tea output on world prices. In the second experiment, higher productivity in tea and resulting output increases depress the producer price. A sufficiently large reduction in the producer price (due, e.g., to less elastic world demand) could produce an immizerizing growth outcome in which producers' gains from technical progress are more than offset by a price decline, causing upland tea area to contract rather than expand. In this case, technical progress in tea could have the perverse effect of being associated with an increase in erosion, and the economic benefits of the technical progress would have to be 
weighed against the additional erosion losses in assessing the net effect on aggregate economic welfare.

This raises an important issue regarding likely future developments in Sri Lanka, where a major expansion of the VP tea area is expected to occur in coming years. Although the outcome should be favorable in terms of conventional economic welfare measures, the negative world price-effect of the associated production increase could result in a larger volume of tea coming from a smaller area. Marginal tea lands are likely to shift into production of other crops. Unless economically attractive erosion control technologies are developed for such lands, the spread of VP tea and associated tea output increases in the face of inelastic world demand may well have indirect environmental costs. If the off-site economic effects are large, the economic costs of land degradation may even dominate the benefits of a more productive tea sector.

\section{CONCLUSIONS}

The quantitative analysis of the impact of policy reforms on the environment has gained in importance as many developing countries implement trade policy liberalization packages. These policy changes alter relative profitability of production in different sectors, and may thus lead to major changes in the structure of production, income, and consumption. Economic liberalization can generate significant environmental impacts when it involves reallocation of resources among activities with differing propensities to generate environmental damage. Given the increasing economic importance assigned to environmental quality, assessments of net social benefits of policy liberalization should take account of environmental changes predicted to occur as a result. Our experiments with a model of the Sri Lankan economy indicate that the economic benefits of trade liberalization may well be augmented by environmental gains in the form of reduced rates of agricultural land degradation and erosion-related off-site soil damage.

In this study we have presented an analytical framework and a general equilibrium modeling approach appropriate for the examination of land degradation in Sri Lanka in the context of major policy reforms and productivity changes in key agricultural sectors. Both the model and database have a number of limitations deriving from lack of information; these are being addressed in continuing 
work. Despite the relative simplicity with which it treats soil erosion and land degradation issues, our model constitutes a substantial extension of previously developed AGE models of the Sri Lankan economy. More generally, it demonstrates that key policyenvironment linkages can be incorporated in AGE models and used to generate results with significant policy content.

\section{REFERENCES}

Athukorala, P., and Jayasuriya, S. (1994) Macroeconomic Policies, Crises, and Growth in Sri Lanka, 1969-90. Washington, DC: The World Bank.

Bandara, J.S. (1989) A Multisectoral General Equilibrium Model of the Sri Lankan Economy with Applications to the Analysis of the Effects of External Shocks. La Trobe University, Melbourne, Australia: unpublished PhD Thesis.

Bandara, J.S. (1990) Recent Experience of Computable General Equilibrium (CGE) Modelling in Sri Lanka: A Survey. UPANATHI - J.Sri Lanka Assoc. Econ. 5:57-82.

Bandara, J.S., and Coxhead, I., in collaboration with Chisholm, A.H., Ekanayake, A., and Jayasuriya, S. (1995) Economic Reforms and the Environment in Sri Lanka. Melbourne: La Trobe University, Agricultural Economics Discussion Paper No. 27/95.

Bandarathilake, H.M. (1994) Optimal Land Use in the Hill Country of Sri Lanka with Particular Applications to Land Degradation and Forestry. MPI/ACIAR Project Draft Report, Colombo.

Barbier, E.B., and Bishop, J.T. (1995) Economic Values and Incentives Affecting Soil and Water Conservation in Developing Countries. Journal of Soil and Water Conservation, March-April:133-137.

Central Bank of Sri Lanka. (1993) Annual Report. Colombo: Central Bank of Sri Lanka. CIE (Centre for International Economics). (1992) The Composition and Level of Effective Taxes for Exporting and Import Competing Production in Sri Lanka. Draft Report Prepared for Sri Lanka Export Development Board, Canberra.

Clark, R. (1994) Economic Evaluation of Soil erosion and Soil Erosion Measures-A Case Study of the Perawelle Area in the Upper Mahaweli Catchment. A Sri Lankan British Project, Technical Report No.20. Polgolla, Sri Lanka: Environmental and Forest Conservation Division, Mahaweli Authority of Sri Lanka.

Cornes, R. (1992) Duality and Modern Economics. Cambridge: Cambridge University Press.

Coxhead, I. (1994) The Welfare and Distributional Consequences of Land Degradation: An Analytical Framework. Paper presented at the Annual Meeting of the American Agricultural Economics Association, San Diego, CA, August 7-10.

Coxhead, I., and Jayasuriya, S. (1995) Trade and Tax Policy Reform and the Environment: The Economics of Soil Erosion in Developing Countries. American Journal of Agricultural Economics 77:631-644.

Coxhead, I., and Shively, G. (1995) Measuring the Environmental Impacts of Economic Change: The Case of Land Degradation in Philippine Agriculture. University of Wisconsin Department of Agricultural Economics, Staff Paper Series No. 384, Madison, WI.

Cruz, W., and Repetto, R. (1992) The Environmental Effects of Stabilization and Structural Adjustment Programs: The Philippines Case. Washington, DC: World Resources Institute. 
Cuthbertson, A.G., and Athukorala, P. (1991) Sri Lanka. In Liberalizing Foreign Trade: Indonesia, Pakistan and Sri Lanka (D. Papageorgiou, M. Michaely, and A.M. Choksi, Eds.). Oxford: Basil Blackwell.

Department of Census and Statistics. (1994). Statistical Abstract of the Democratic Republic of Sri Lanka 1993. Colombo: Ministry of Policy Planning and Implementation.

Dixon, P.B., Parmenter, B.R., Sutton, J., and Vincent, D.P. (1982) ORANI: A Multisectoral Model of the Australian Economy. Amsterdam: North-Holland.

Fuchs, H.J. (1989) Tea Environment and Yield in Sri Lanka. Germany: Margref Scientific Publishers.

Masicat, P., de Vera, V., and Pingali, P. (1990) Philippine Irrigation Infrastructure: Degradation Trends for Luzon, 1966-89. IRRI Social Science Division Papers No. 90-03, International Rice Research Institute, Los Banos, Philippines.

Ministry of Public Administration, Parliamentary Affairs and Plantation Industries. (1994) Plantation Sector-Statistical Pocket Book. Colombo: Ministry of Public Administration.

Pagan, A., and Shannon, E. (1985) How Reliable Are ORANI Conclusions? IMPACT Project Working Paper, University of Melbourne, Melbourne.

Pearson, K.R. (1988) Automating the Computation of Solutions of Large Economic Models. Economics Modelling 5:385-395.

Repetto, R. (1989) Economic Incentives for Sustainable Production. In Environmental Management and Economic Development (G. Schramm and J.J. Warford, Eds.) Baltimore, MD: Johns Hopkins University Press for the World Bank.

Rajapatirana, S. (1988) Foreign Trade and Economic Development: The Case of Sri Lanka. World Development 16:1143-1157.

Sri Lanka Tea Board. (1994) Annual Report 1994. Colombo: Sri Lanka Tea Board.

World Resources Institute. (1989) Wasting Assets: Natural Resources in the National Income Accounts. Washington, DC: World Resources Institute.

World Resources Institute. (1992) Accounts Overdue: Natural Resource Depreciation in Costa Rica. Washington, DC: World Resources Institute.

\section{APPENDIX}

\section{A Summary of the Model Structure}

The main technological and behavioral relationships of the model are derived from the optimality conditions of revenue, cost, and utility functions. The structure of the model is similar to that of the ORANI model of the Australian economy (Dixon et al., 1982); we therefore describe it only in general terms and in greatly simplified form (a complete description is available from the authors). Define the following variables and vectors (in bold; set size in parentheses):

$\mathbf{P}$ commodity prices $(N)$

$\mathbf{R}$ sector-specific factor prices $(N)$

$\mathbf{X}$ mobile factor demands $(N F)$

$\mathbf{S}$ net imports $(N)$

$U$ aggregate utility (1).
W mobile factor prices $(F)$

Y domestic commodity supplies $(N)$

D domestic final demands $(N)$

V factor endowments $(F)$

$\Phi \quad$ Foreign currency exchange rate (1) 
Suppose factor endowments and commodity prices to be given, and let $\Phi=1$ be the numeraire price. Aggregate revenue (i.e., GNP) is given by $G(\mathbf{P}, \mathbf{V})=\max \{\mathbf{P} \cdot \mathbf{Y} \mid \mathbf{V}\}$; from the first-order conditions of this problem we obtain, by Shephard's lemma, sectoral supply functions:

$$
Y_{j}=Y_{j}(\mathbf{P}, \mathbf{V}) \quad(j=1, \ldots, N),
$$

and prices of mobile and specific factors:

$$
\begin{aligned}
W_{i} & =W_{i}(\mathbf{P}, \mathbf{V}) & & (i=1, \ldots, F) \\
R_{j} & =R_{j}(\mathbf{P}, \mathbf{V}) . & & (j=1, \ldots, N) .
\end{aligned}
$$

Each sector is assumed to be a price-taker in factor markets. Therefore, the output level that maximizes revenue in Equation A1 is also the cost-minimizing level, and from the first-order conditions of sectoral cost minimization $C_{j}\left(\mathbf{W}, Y_{j}\right)=\min \left\{\mathbf{W} \cdot \mathbf{X} \mid Y_{j}\right\}$, we obtain mobile factor demands:

$$
X_{i j}=X_{i j}\left(\mathbf{W}, Y_{j}\right) \quad(i=1, \ldots, F ; j=1, \ldots, N) .
$$

Domestic final demands for each commodity are found by Shephard's lemma from the first-order conditions of the expenditure minimization problem $E(\mathbf{P}, U)=\min \{\mathbf{P} \cdot \mathbf{D} \mid U\}$ :

$$
D_{j}=D_{j}(\mathbf{P}, U) \quad(j=1, \ldots, N) .
$$

Net commodity trade volumes are determined by market-clearing conditions:

$$
S_{j}=D_{j}-Y_{j} \quad(j=1, \ldots, N),
$$

while for $M$ exportables $(M \subset N)$, prices are set by inverse foreign demand functions:

$$
P_{k}=P_{k}\left(S_{k}\right) \quad(k=1, \ldots, M) .
$$

Finally, the model is closed by an aggregate budget constraint:

$$
E(\mathbf{P}, U)=G(\mathbf{P}, \mathbf{V})
$$

There are $4 N+F+F N+M+1$ equations in the system (Equations A1-A8), but the model contains $5 N+2 F+\mathrm{FN}+2$ variables. In a short-run neoclassical closure $\mathbf{V}$ is declared exogenous, and so is a subset $(N-M)$ of $\mathbf{P}$. The exchange rate $\Phi$ is selected as numeraire price. The number of equations is thus made equal to the number of endogenous variables, and A1-A8 solve for $\mathbf{Y}, \mathbf{W}, \mathbf{R}, \mathbf{X}, \mathbf{D}, \mathbf{N}, U$, and $M$ elements of $\mathbf{P}$. Alternative closures 
Table A1: Effects of Exogenous Shocks on Sector Output (Percent Changes)

\begin{tabular}{|c|c|c|c|}
\hline & $\begin{array}{c}\text { Classification } \\
(\mathbf{X} / \mathbf{M} / \mathbf{N})\end{array}$ & $\begin{array}{l}25 \% \text { Tariff } \\
\text { reduction }\end{array}$ & $\begin{array}{l}10 \% \text { Technical } \\
\text { progress in tea }\end{array}$ \\
\hline Upland tea & $\mathrm{N}$ & 2.8 & 13.0 \\
\hline Lowland tea & $\mathrm{N}$ & 6.5 & 16.7 \\
\hline Rubber & $\mathrm{X}$ & 1.1 & -2.3 \\
\hline Coconut & $\mathrm{N}$ & 0.6 & 0.6 \\
\hline Paddy & $\mathrm{N}$ & 0.3 & 0.5 \\
\hline Export agr. & $\mathrm{X}$ & 0.7 & -1.6 \\
\hline Upland other agr. & M & -1.1 & -1.1 \\
\hline Lowland other agr. & M & -0.4 & -0.3 \\
\hline Plantation dev. & $\mathrm{N}$ & 0.0 & 0.0 \\
\hline Fisheries & $\mathrm{N}$ & 0.3 & 0.5 \\
\hline Forestry & $\mathrm{N}$ & 0.3 & 0.5 \\
\hline Mining & $\mathrm{X}$ & 1.4 & -3.0 \\
\hline Tea processing & $\mathrm{X}$ & 4.3 & 14.5 \\
\hline Coconut processing & $\mathrm{X}$ & 1.9 & -4.4 \\
\hline Rice processing & $\mathrm{N}$ & 1.1 & -0.6 \\
\hline Other food & M & -1.4 & -0.5 \\
\hline Textiles & M & 0.5 & 0.1 \\
\hline Clothing & $\mathrm{X}$ & 1.4 & -1.9 \\
\hline Wood products & $\mathrm{M}$ & 0.1 & 0.2 \\
\hline Paper products & M & 0.6 & 1.0 \\
\hline Fert and chemicals & M & 0.2 & 0.4 \\
\hline Petroleum & M & 0.8 & 0.2 \\
\hline Rubber products & $\mathrm{X}$ & 1.4 & -1.4 \\
\hline Glass and cement & M & -0.4 & 0.2 \\
\hline Basic metals & M & -0.4 & -0.3 \\
\hline Fabr. metal prod. & M & -2.4 & -0.4 \\
\hline Machinery and equipment & M & -0.5 & -1.0 \\
\hline Electrical equipment & M & -1.0 & -0.4 \\
\hline Transport equipment & M & -0.9 & -0.1 \\
\hline Other manufacturing & $\mathrm{X}$ & 2.6 & -1.8 \\
\hline Electricity and gas & $\mathrm{N}$ & 0.4 & 0.6 \\
\hline Construction & $\mathrm{N}$ & 0.1 & 0.2 \\
\hline Trade & $\mathrm{N}$ & 0.6 & 0.7 \\
\hline Finance & $\mathrm{N}$ & 0.0 & 0.1 \\
\hline Housing & $\mathrm{N}$ & 0.0 & 0.0 \\
\hline Public administration & $\mathrm{N}$ & 0.6 & 1.0 \\
\hline Personal services & $\mathrm{N}$ & 0.5 & 0.9 \\
\hline
\end{tabular}

Note: $\mathrm{X}=$ exportable; $\mathrm{M}=$ importable; $\mathrm{N}=$ non-traded. 
may be specified by selecting different subsets of variables to be exogenous. In our simulations, for example, we fix the real wage. This amounts to fixing $W_{L} / \mathbf{P}$ and allowing the value of the corresponding factor endowment, $V_{L}$ (reinterpreted as total employment), to be solved within the model.

In an economy with constant returns to scale, equilibrium requires that factor and product markets clear, that aggregate expenditure is equal to income, and that trade is in balance. In this model factor market clearing is implied by the conditions for revenue maximization, and the markets for non-traded commodities (for which $S_{j}=0$ ) clear by Equation A6. Aggregate expenditures are set equal to income in Equation A8. By Walras' law, when these conditions are all met, the balance of trade is also zero, thus satisfying the conditions for general equilibrium.

Our simulation model adds considerable complexity but does not alter this basic framework. It allows for intermediate inputs, distinguished by source (domestic or foreign), and distinguishes between three types of labor input-skilled, rural, and urbanwhich are combined to create a composite labor input. Factor and intermediate input productivity is alterable to represent inputspecific technical progress in each sector. Final demands for domestic and imported commodities are distinguished also by category-households, government, net trade, and capital creation. Government commodity demand and demands for capital creation are exogenous. There are zero pure profits in production, trade, and capital creation. In each sector we allow for trade and transport margins proportional to the relevant commodity flows. Imperfect substitution between domestic and foreign goods allows domestic and foreign prices of the same good to differ; in addition, we allow for taxes, tariffs, and subsidies to drive wedges between domestic and foreign prices of identical goods. All substitution relationships on both supply and demand sides of the model are CES, except intermediate input demands, which are Leontief.

To this basic structure we add relationships governing land mobility among some agricultural sectors as well as accounting equations for land degradation. There are set out and explained in the text. The model is solved in linearized form using Gempack software (Pearson, 1988). 